\title{
Short-Term Regulation of Adiponectin Secretion in Rat Adipocytes
}

\author{
T. SZKUDELSKI ${ }^{1}$, L. NOGOWSKI ${ }^{1}$, K. SZKUDELSKA ${ }^{1}$ \\ ${ }^{1}$ Department of Animal Physiology and Biochemistry, Poznan University of Life Sciences, Poznan, \\ Poland
}

Received February 2, 2010

Accepted October 11, 2010

On-line March 14, 2011

\section{Summary}

Adiponectin belongs to the group of biologically active substances secreted by adipocytes and referred to as adipokines. Disturbances in its secretion and/or action are thought to be involved in the pathogenesis of some metabolic diseases. However, regulation of adiponectin secretion is poorly elucidated. In the present study, short-term regulation of adiponectin secretion in primary rat adipocytes was investigated. Isolated rat adipocytes were incubated in Krebs-Ringer buffer containing $5 \mathrm{mM}$ glucose and insulin alone or in the combination with epinephrine, dibutyryl-cAMP, adenosine $A_{1}$ receptor antagonist (DPCPX), palmitate, 2-bromopalmitate or inhibitor of mitochondrial electron transport (rotenone). Adipocyte exposure for $2 \mathrm{~h}$ to insulin (1-100 $\mathrm{nM}$ ) significantly increased secretion of adiponectin compared with secretion observed without insulin. Furthermore, secretion of adiponectin from adipocytes incubated with glucose and insulin was reduced by 1 and $2 \mu \mathrm{M}$ epinephrine, but not by 0.25 and $0.5 \mu \mathrm{M}$ epinephrine. Under similar conditions, 1 and $2 \mathrm{mM}$ dibutyryl-cAMP substantially diminished secretion of adiponectin, whereas $0.5 \mathrm{mM}$ dibutyryl-cAMP was ineffective. Secretion of adiponectin was found to be effectively decreased by DPCPX. Moreover, adipocyte exposure to rotenone also resulted in a substantial diminution of secretory response of adipocytes incubated for $2 \mathrm{~h}$ with glucose and insulin. It was also demonstrated that palmitate and 2-bromopalmitate (0.06-0.5 $\mathrm{mM}$ ) failed to affect secretion of leptin. The obtained results indicated that in short-term regulation of adiponectin secretion, insulin and epinephrine exert the opposite effects. These effects appeared as early as after $2 \mathrm{~h}$ of exposure. Moreover, deprivation of energy or blockade of adenosine action substantially decreased secretion of adiponectin.

\section{Key words}

Adipocytes • Adiponectin • Secretion • Regulation

\section{Corresponding author}

Tomasz Szkudelski, Department of Animal Physiology and Biochemistry, Poznan University of Life Sciences, Wolynska 35, 60-637 Poznan, Poland. Fax: +48 61 8487197. E-mail: tszkudel@jay.up.poznan.pl

\section{Introduction}

Diabetes mellitus is a serious disease affecting about $5 \%$ people worldwide. Type 2 diabetes is the most frequent and accounts for almost $90 \%$ of all types of diabetes. This type of diabetes is mainly characterized by impaired insulin secretion and action. Environmental factors, such as high calorie diet and low physical activity, are thought to play very important role in the pathogenesis of type 2 diabetes. It is well established that the incidence of type 2 diabetes is highly related to obesity and that increased adipocyte lipid storage contributes to reduced insulin action (Leahy 2005). However, adipose tissue is not only a reservoir of energy, but is also recognized as an endocrine organ since it secrets biologically active factors referred to as adipokines. Disturbances in secretion and/or action of some adipokines are also known to contribute to the onset of type 2 diabetes (Rabe et al. 2008).

Adiponectin is one of the adipocyte-derived factors, the role of which in the pathogenesis of type 2 diabetes is quite well elucidated not only in rodents but also in humans (reviewed by Haluzík et al. 2004, Nedvídková et al. 2005, Ziemke and Mantzoros 2010). It is known that diminished levels of blood adiponectin contribute to obesity-related insulin resistance and diabetes, whereas increased blood adiponectin exerts the opposite effect. It was also demonstrated that exogenous adiponectin effectively ameliorates insulin resistance 
(Yamauchi et al. 2001). On the other hand, adiponectin resistance, induced by a high-fat diet, causes dysregulation of lipid metabolism in skeletal muscles and contributes to the development of insulin resistance (Mullen et al. 2009). An inverse correlation between adiposity and blood adiponectin is well documented (Arita et al. 1999, Matsubara et al. 2002, Yamamoto et al. 2002). Importantly, weight reduction significantly increases blood adiponectin levels in both diabetic and nondiabetic subjects (Hotta et al. 2000).

The mechanism of adiponectin action at the cellular level is only partially known. This action is preceded by adiponectin binding to its membrane receptors (AdipoR1 and AdipoR2) found in different tissues (Yamauchi et al. 2003) and involves activation of adenosine-5'-monophosphate-activated protein kinase (AMPK) (Yamauchi et al. 2002, Huypens et al. 2005, Wang et al. 2007) and reduction of serine phosphorylation of insulin receptor substrate mediated by p70 S6 kinase and mammalian target of rapamycin (Wang et al. 2007). As a result, adiponectin sensitizes insulin signaling (Wang et al. 2007) and improves insulin action (Yamauchi et al. 2001, Berg et al. 2001)

Despite a large body of evidence pointing to adiponectin as an adipocyte-derived factor which plays an important role in preventing some metabolic diseases, little is known about regulation of its secretion. Moreover, the majority of results arises from long-term experiments in which cells were incubated for many hours or even days. In the present study, short-term regulation of adiponectin secretion in isolated rat adipocytes was investigated under different experimental conditions.

\section{Methods}

\section{Animals}

In each experiment, male Wistar rats that weighed 260-280 $\mathrm{g}$ and obtained from Brwinow (Poland) were used. Rats were maintained in cages in an air-conditioned room at a constant temperature of $21 \pm 1$ ${ }^{\circ} \mathrm{C}$ with a 12:12-h dark-light cycle. Animals were fed a standard laboratory chow (Labofeed, Poland) and had free access to drinking water. The experiments were performed according to rules and protocols accepted by Local Ethical Commission for Investigations on Animals.

\section{Isolation of adipocytes}

Fat cells were isolated as described previously
(Rodbell 1964) with modifications (Szkudelska et al. 2000). In brief, the animals were slaughtered by decapitation and the epididymal fat tissue was collected and rinsed with $0.9 \% \mathrm{NaCl}$. Large blood vessels were removed, fat tissue was cut into small pieces and incubated with gentle shaking for $90 \mathrm{~min}$ at $37{ }^{\circ} \mathrm{C}$ in Krebs-Ringer buffer containing $3 \%$ bovine serum albumin, $3 \mathrm{mM}$ glucose, $10 \mathrm{mM}$ HEPES and $2 \mathrm{mg} / \mathrm{ml}$ collagenase. Before use, the buffer was gassed for 20 min with a mixture of $\mathrm{O}_{2} / \mathrm{CO}_{2}(95 \% / 5 \%)$ and $\mathrm{pH}$ was adjusted to 7.4. Afterwards, the adipocytes were filtered through a nylon mesh, rinsed with Krebs-Ringer buffer without collagenase and counted under the microscope with a Bürker-Türk counting chamber.

\section{Incubations of adipocytes}

In order to investigate the mechanisms involved in the short-term regulation of adiponectin secretion, adipocytes were exposed to different agents which potentially could affect secretory activity of these cells. In each experiment, cells $\left(10^{5} / \mathrm{ml}\right)$ were incubated in plastic tubes containing Krebs-Ringer buffer with $3 \%$ bovine serum albumin (except for experiments with palmitate and 2-bromopalmitate) and $10 \mathrm{mM}$ HEPES. Incubations were made at $37{ }^{\circ} \mathrm{C}$ with gentle shaking.

In the first part of the study, the effects of insulin on adiponectin secretion were studied. In these experiments, fat cells were incubated without insulin or with $0.1,1,10$ and $100 \mathrm{nM}$ insulin. All incubations were performed for $2 \mathrm{~h}$ in Krebs-Ringer buffer containing $5 \mathrm{mM}$ glucose. Additionally, adipocytes were incubated for 2 or $4 \mathrm{~h}$ in the buffer without glucose and insulin or in the presence of $5 \mathrm{mM}$ glucose and $10 \mathrm{nM}$ insulin.

To determine the effects of epinephrine on adiponectin secretion, isolated cells were incubated for $2 \mathrm{~h}$ in the medium containing $5 \mathrm{mM}$ glucose and $10 \mathrm{nM}$ insulin or $5 \mathrm{mM}$ glucose, $10 \mathrm{nM}$ insulin and $0.25,0.5$, 1 or $2 \mu \mathrm{M}$ epinephrine. Furthermore, the effects of dibutyryl-cAMP, a non-hydrolysable cAMP analogue, on adiponectin secretion were investigated. In these experiments, fat cells were incubated for $2 \mathrm{~h}$ with $5 \mathrm{mM}$ glucose and $10 \mathrm{nM}$ insulin alone or in the combination with $0.5,1$ or $2 \mathrm{mM}$ dibutyryl-cAMP.

The role of adipocyte-derived adenosine in the short-term regulation of adiponectin secretion was also determined. For this purpose, adipocytes were incubated for $2 \mathrm{~h}$ with $5 \mathrm{mM}$ glucose and $10 \mathrm{nM}$ insulin alone or in the presence of $0.5,1$ or $2 \mu \mathrm{M}$ DPCPX, an adenosine $\mathrm{A}_{1}$ receptor antagonist. 
Additionally, the effects of palmitate and 2-bromopalmitate on adiponectin secretion from isolated rat adipocytes were studied. In these experiments, fat cells were incubated for $2 \mathrm{~h}$ in the medium containing $5 \mathrm{mM}$ glucose with $10 \mathrm{nM}$ insulin alone or in the presence of palmitate or 2-bromopalmitate. Both fatty acids were tested at concentrations $0.06,0.125,0.25$ or $0.5 \mathrm{mM}$. In the experiments with palmitate and 2bromopalmitate, the concentration of albumin in the buffer was diminished to $0.1 \%$.

The effects of diminished ATP concentration on adiponectin secretion were also tested. In this part of the study, adipose cells were incubated for $2 \mathrm{~h}$ with 5 $\mathrm{mM}$ glucose and $10 \mathrm{nM}$ insulin or were exposed to glucose and insulin in the presence of 1.25, 2.5, 5 and $10 \mu \mathrm{M}$ rotenone, a potent and specific inhibitor of mitochondrial electron transport.

\section{Determination of adiponectin, glycerol and ATP}

At the end of each incubation, adipocytes were removed and adiponectin concentrations in the medium were measured by radioimmunoassay using kits provided by Linco Research, Inc. (USA).

Epinephrine, dibutyryl-cAMP and DPCPX are known lipolytic agents. To ensure that they are effective, in each experiment employing these agents, glycerol release from adipocytes to the incubation medium was determined. At the end of incubations, adipocytes were aspirated and aliquots of the incubation buffer were taken and frozen until analysis. The concentration of glycerol was measured colorimetrically according to the method described by Foster and Dunn (1973).

In the experiments with rotenone, ATP concentrations were determined. At the end of each incubation with rotenone, the lysis reagent was added, the tubes were vortexed, left in room temperature for a few min and the upper phase was removed. Afterwards, ATP was measured by a luminometric method using a kit containing firefly luciferase and luciferine.

\section{Viability of adipocytes}

Cell viability was assessed via Trypan blue exclusion. Adipocytes were incubated for $2 \mathrm{~h}$ at $37{ }^{\circ} \mathrm{C}$ in Krebs-Ringer buffer containing $5 \mathrm{mM}$ glucose, 10 $\mathrm{nM}$ insulin, $3 \% \mathrm{BSA}$ and $10 \mathrm{mM}$ HEPES. At the end of the incubation, cells were suspended in Trypan blue solution and were observed under the microscope. Viability of adipocytes was no less than $95 \%$.

\section{Reagents}

D-glucose, bovine serum albumin (fraction V), collagenase (EC 3.4.24.3, from Clostridium histolyticum, type II), insulin (from bovine pancreas), dibutyryl-cAMP, DPCPX, epinephrine, rotenone, palmitate, 2-bromopalmitate, lysis reagent (somatic cell ATP releasing reagent; Sigma catalogue symbol FLSAR), DMSO, kits used to determine ATP, trypan blue $(0.4 \%)$ and all reagents used to prepare Krebs-Ringer buffer were from Sigma (St. Louis, MO, USA). Stock solutions of rotenone, DPCPX, palmitate and 2-bromopalmitate were prepared in dimethyl sulfoxide and $5 \mu \mathrm{l}$ of the solution per $950 \mu \mathrm{l}$ of Krebs-Ringer buffer with adipocytes was added. The composition of Krebs-Ringer buffer was the following (in $\mathrm{mM}$ ): $118 \mathrm{NaCl}, 4.8 \mathrm{KCl}, 1.3 \mathrm{CaCl}_{2}$, $1.2 \mathrm{KH}_{2} \mathrm{PO}_{4}, 1.2 \mathrm{MgSO}_{4}, 24.8 \mathrm{NaHCO}_{3}$.

\section{Statistical analysis}

The means \pm S.E.M. were obtained from three independent experiments in quadruplicate and were evaluated statistically using analysis of variance and Duncan's multiple range test. Differences were considered significant at $\mathrm{p}<0.05$.

\section{Results}

\section{Effects of insulin on adiponectin secretion}

It was demonstrated that insulin, present in the incubation medium at concentrations $0.1,1,10$ and $100 \mathrm{nM}$, increased secretion of adiponectin by 7 (non significant), 15, 21 and $23 \%$, respectively, compared with results noticed without insulin. These observations were made in the presence of $5 \mathrm{mM}$ glucose (Fig. 1). Further studies revealed that the combination of $5 \mathrm{mM}$ glucose and $10 \mathrm{nM}$ insulin enhanced secretion of adiponectin, after 2 and $4 \mathrm{~h}$ of incubation, by 32 and $56 \%$, respectively, compared with secretion found in adipocytes incubated without glucose and insulin (Fig. 1).

Effects of epinephrine, dibutyryl-cAMP and adenosine $A_{1}$ receptor antagonist on adiponectin secretion

Adipocyte exposure to $0.25 \mu \mathrm{M}$ epinephrine failed to affect adiponectin secretion in the presence of $5 \mathrm{mM}$ glucose and $10 \mathrm{nM}$ insulin. Similar lack of effect was noticed when cells were incubated with $0.5 \mu \mathrm{M}$ epinephrine. Interestingly, $0.5 \mu \mathrm{M}$ epinephrine did not affect adiponectin secretion despite a significant rise in lipolysis. However, incubation of fat cells with 1 and $2 \mu \mathrm{M}$ epinephrine significantly affected both adiponectin 
secretion and lipolysis. Under these conditions, secretion of adiponectin was diminished by $22 \%$ and $25 \%$, respectively, compared with results obtained without epinephrine (Fig. 2).
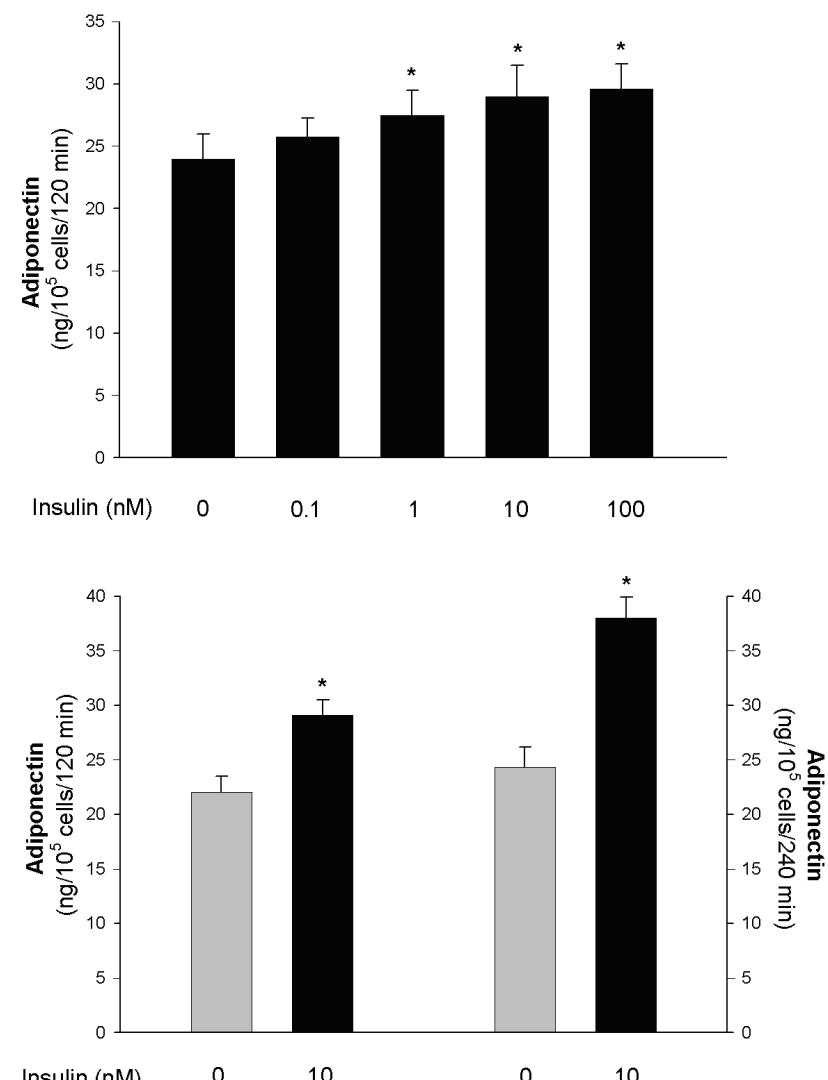

Insulin (nM) $\quad 0 \quad 10$

10

Fig. 1. The effect of glucose and insulin on adiponectin secretion from isolated rat adipocytes. Adipocytes were incubated without glucose and insulin (gray bars) or with $5 \mathrm{mM}$ glucose in the presence of different concentrations of insulin (black bars). Bars represent mean \pm SEM of 12 determinations from 3 separate experiments. * Differences statistically significant vs. incubations without insulin (upper plot) or vs. incubations without insulin and glucose (lover plot), $\mathrm{P}<0.05$.

Secretion of adiponectin tested in the presence of $5 \mathrm{mM}$ glucose and $10 \mathrm{nM}$ insulin tended to be diminished by $0.5 \mathrm{mM}$ dibutyryl-cAMP. This effect was not statistically significant despite increased lipolysis. However, adiponectin secretion was reduced by 24 and $37 \%$, respectively, when 1 and $2 \mathrm{mM}$ dibutyryl-cAMP was present in the incubation buffer. This effect was accompanied by a substantial increase in lipolysis (Fig. 3).

Adenosine $A_{1}$ receptor blockade significantly affected secretion of adiponectin from isolated rat adipocytes. Fat cells incubated with $5 \mathrm{mM}$ glucose and $10 \mathrm{nM}$ insulin and exposed to $0.5,1$ or $2 \mu \mathrm{M}$ DPCPX released less adiponectin, by 23,25 and $26 \%$, respectively, compared with adipocytes incubated without DPCPX. Simultaneously, 0.5, 1 and $2 \mu \mathrm{M}$ DPCPX significantly increased glycerol release from adipocytes to the incubation medium (Fig. 4).
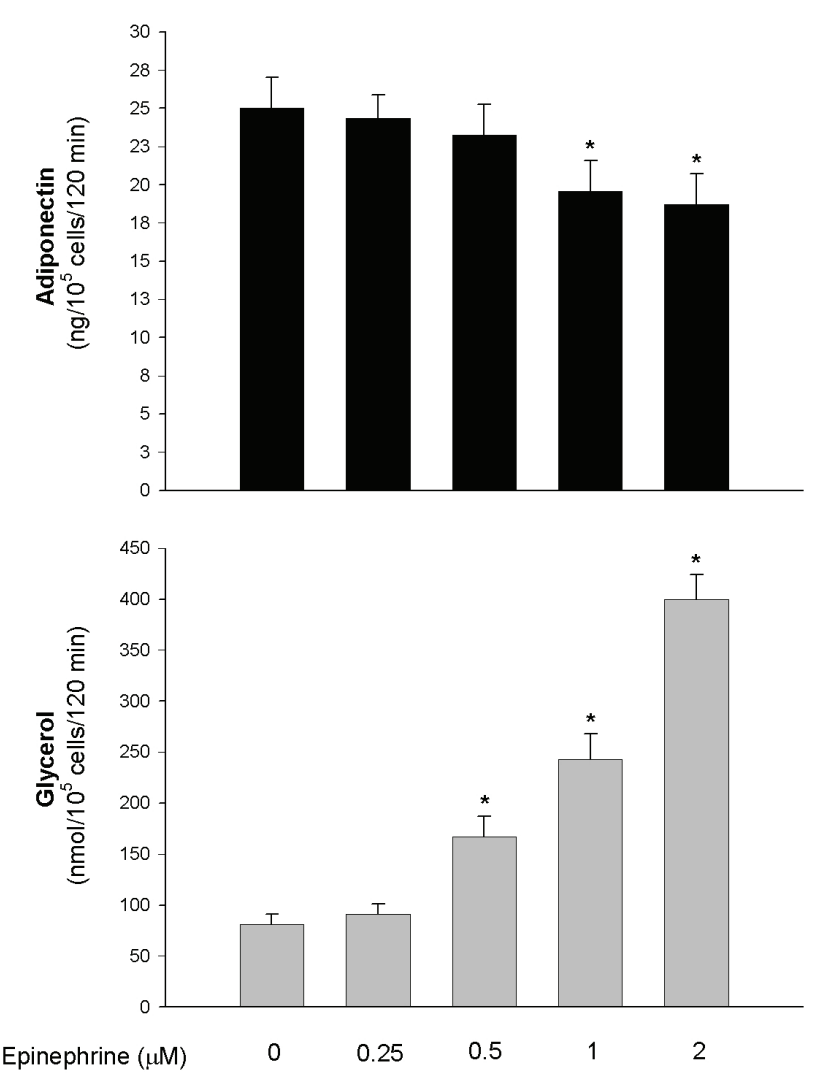

Fig. 2. The effect of epinephrine on adiponectin secretion (upper plot) or glycerol release (lower plot) from isolated rat adipocytes. Adipocytes were exposed to $5 \mathrm{mM}$ glucose and $10 \mathrm{nM}$ insulin without epinephrine or in the presence of different concentrations of this hormone. Bars represent mean \pm SEM of 12 determinations from 3 separate experiments. * Differences statistically significant vs. incubations without epinephrine, $\mathrm{P}<0.05$.

Effects of palmitate and 2-bromopalmitate on adiponectin secretion

Adipocyte exposure to $0.06,0.125,0.25$ and $0.5 \mathrm{mM}$ palmitate failed to affect secretion of adiponectin from adipocytes incubated for $2 \mathrm{~h}$ in the presence of $5 \mathrm{mM}$ glucose and $10 \mathrm{nM}$ insulin. Similarly to palmitate, its non-metabolisable analogue, 2-bromopalmitate, was also ineffective and did not change secretion of adiponectin (Fig. 5).

\section{Effects of energy deprivation on adiponectin secretion}

In the present study, adipocytes incubated with $5 \mathrm{mM}$ glucose and $10 \mathrm{nM}$ insulin and exposed to rotenone released less adiponectin compared with cells 

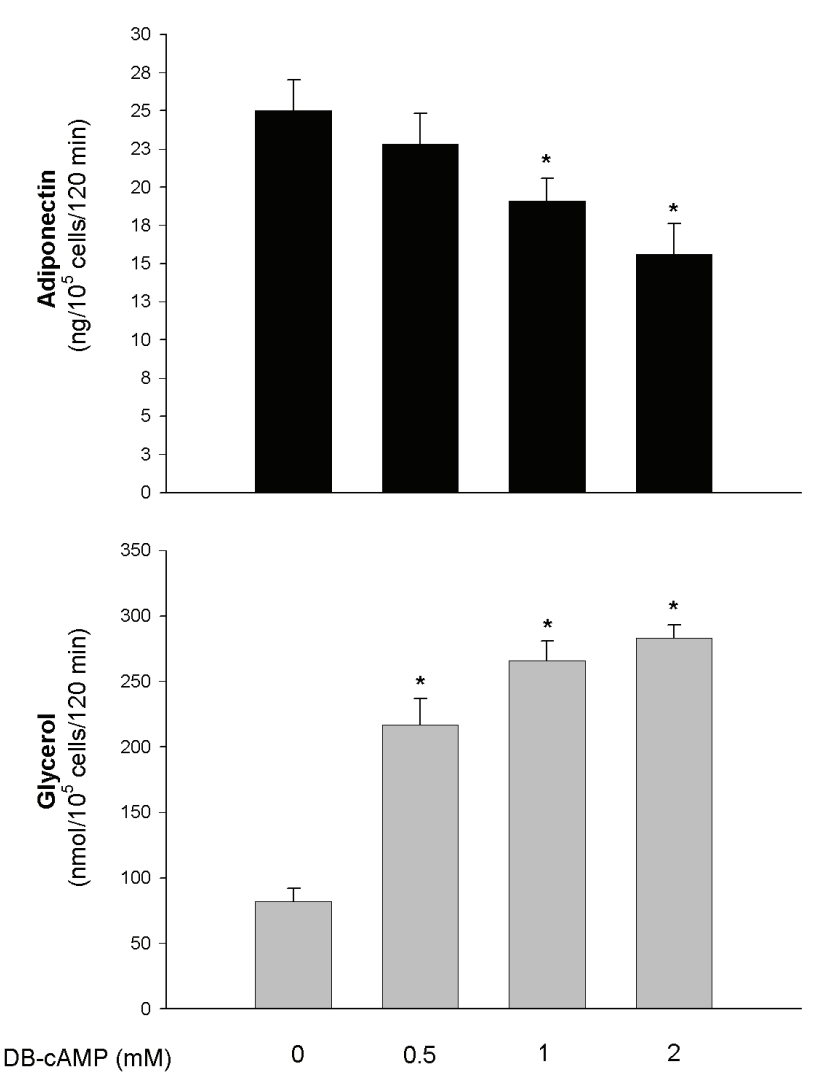

Fig. 3. The effect of dibutyryl-cAMP (DB-cAMP) on adiponectin secretion (upper plot) or glycerol release (lower plot) from isolated rat adipocytes. Adipocytes were exposed to $5 \mathrm{mM}$ glucose and $10 \mathrm{nM}$ insulin without DB-CAMP or in the presence of different concentrations of this compound. Bars represent mean \pm SEM of 12 determinations from 3 separate experiments. * Differences statistically significant vs. incubations without DBcAMP, $\mathrm{P}<0.05$.

incubated with glucose and insulin without rotenone. It was found that $1.25,2.5,5$ and $10 \mu \mathrm{M}$ rotenone diminished secretion of adiponectin by 45, 47, 51 and $49 \%$, respectively. As expected, adipocyte exposure to rotenone resulted in a profound reduction of intracellular ATP (Fig. 6).

\section{Discussion}

Insulin is one of the pivotal physiological factors regulating different adipocyte functions, including secretion of leptin. Insulin increases secretion of leptin via pleiotropic action involving changes in leptin gene expression, activation of mTOR (mammalian target of rapamycin), stimulation of glucose transport and metabolism, increased release of adenosine, diminution of cAMP and inhibition of lipolysis (reviewed by Szkudelski 2007). However, the regulatory role of insulin in adiponectin secretion is still elusive. Our present study revealed the stimulatory effect of insulin in the presence
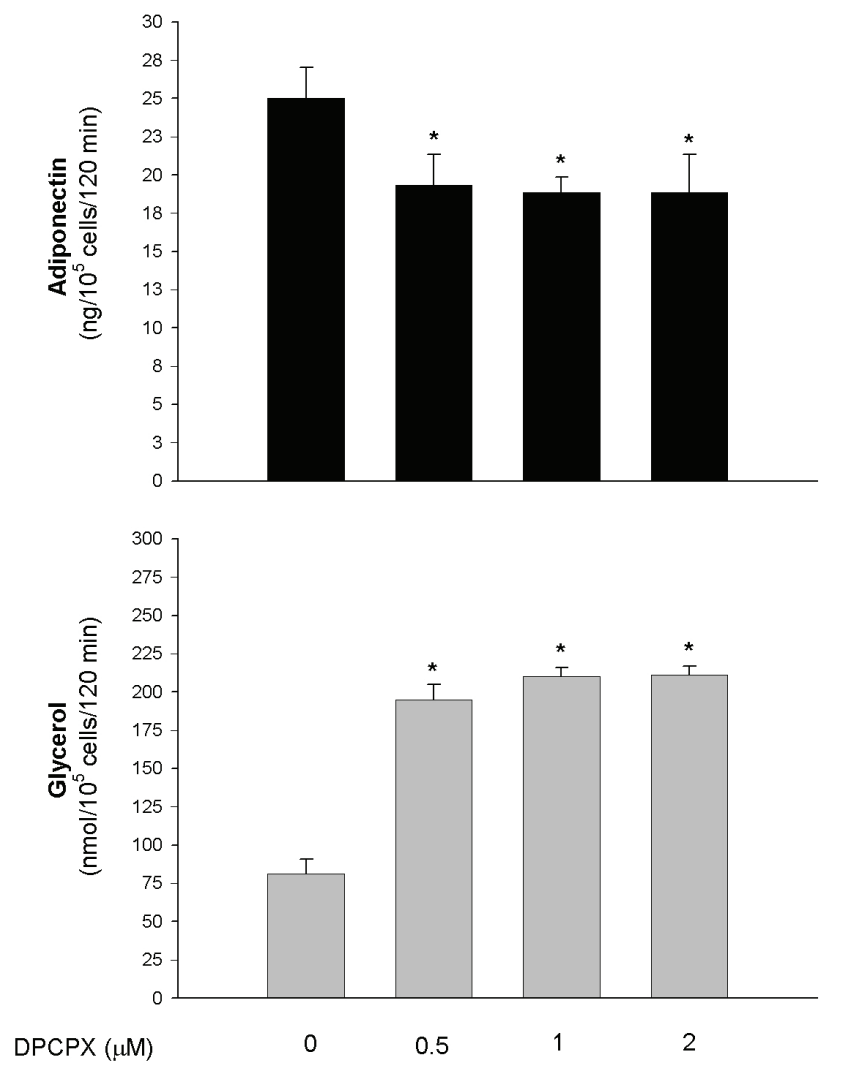

Fig. 4. The effect of adenosine $A_{1}$ receptor antagonist (DPCPX) on adiponectin secretion (upper plot) or glycerol release (lower plot) from isolated rat adipocytes. Adipocytes were exposed to $5 \mathrm{mM}$ glucose and $10 \mathrm{nM}$ insulin without DPCPX or in the presence of different concentrations of this compound. Bars represent mean \pm SEM of 12 determinations from 3 separate experiments. * Differences statistically significant vs. incubations without DPCPX, $\mathrm{P}<0.05$.

of $5 \mathrm{mM}$ glucose on adiponectin secretion after 2 and $4 \mathrm{~h}$ of incubation. The maximal secretory response to insulin, used at concentration as high as $100 \mathrm{nM}$, was $23 \%$. Cong et al. (2007) have previously shown the stimulatory effect of $20 \mathrm{nM}$ insulin on adiponectin secretion from rat adipocytes incubated for $4 \mathrm{~h}$ in the presence of $25 \mathrm{mM}$ glucose, however, after 8-24 h of exposure, insulin completely failed to enhance secretion of adiponectin. It should be also mentioned that the secretory response of adipocytes to insulin differs in various adipose tissue compartments. Motoshima et al. (2002) demonstrated no effect of insulin on adiponectin secretion from subcutaneous adipocytes, whereas cells obtained from omental fat tissue secreted more adiponectin upon insulin exposure. Results of our present study revealed the ability of insulin to increase secretion of adiponectin from epididymal rat adipocytes.

Taking into account data from the literature and results obtained in this study, it can be ascertained that the effects of insulin on adiponectin secretion are rather 


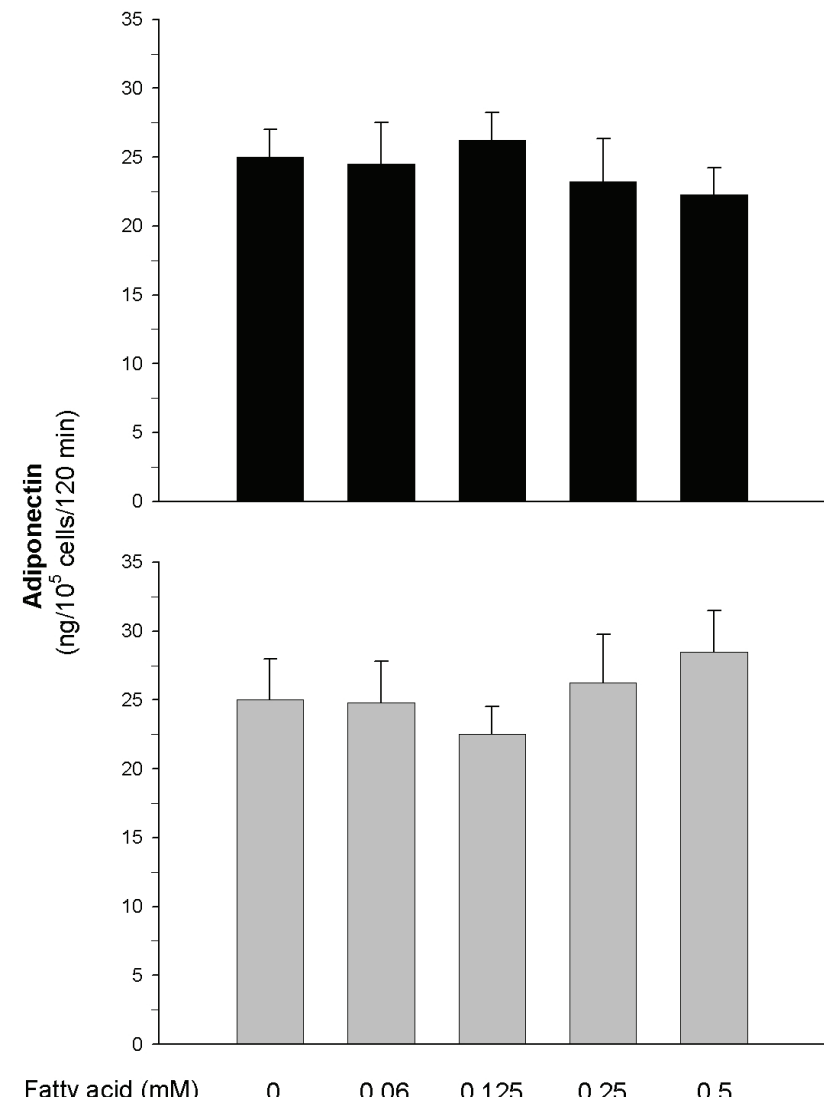

$\begin{array}{llllll}\text { Fatty acid }(\mathrm{mM}) & 0 & 0.06 & 0.125 & 0.25 & 0.5\end{array}$

Fig. 5. The effect of palmitate (upper plot) and 2-bromopalmitate (lower plot) on adiponectin secretion from isolated rat adipocytes. Adipocytes were incubated in the presence of $5 \mathrm{mM}$ glucose and $10 \mathrm{nM}$ insulin without fatty acids or in the presence of different concentrations of those compounds. Bars represent mean \pm SEM of 12 determinations from 3 separate experiments.

small. This may have physiological relevance since in different conditions, such as obesity, diabetes and fasting, blood adiponectin seems not to be correlated with changes in insulinemia. It is known that plasma adiponectin is low in obesity and type 2 diabetes despite concomitant hyperinsulinemia (Weyer et al. 2001). In patients with type 1 diabetes, plasma adiponectin is reported to be usually increased (Lindström et al. 2006, Peczyńska et al. 2008). Moreover, fasting significantly affects adiponectinemia neither in rats (Zhang et al. 2002) nor in humans (Gavrila et al. 2003) despite reduced blood insulin.

Apart from insulin, under physiological conditions numerous factors, including epinephrine and adipocyte-derived adenosine, change intracellular cAMP and thereby affect metabolism of adipocytes. Adrenergic stimulation increases cAMP levels and enhances lipid release. This is accompanied by reduced secretion of leptin (Gettys et al. 1996, Cammisotto and Bukowiecki
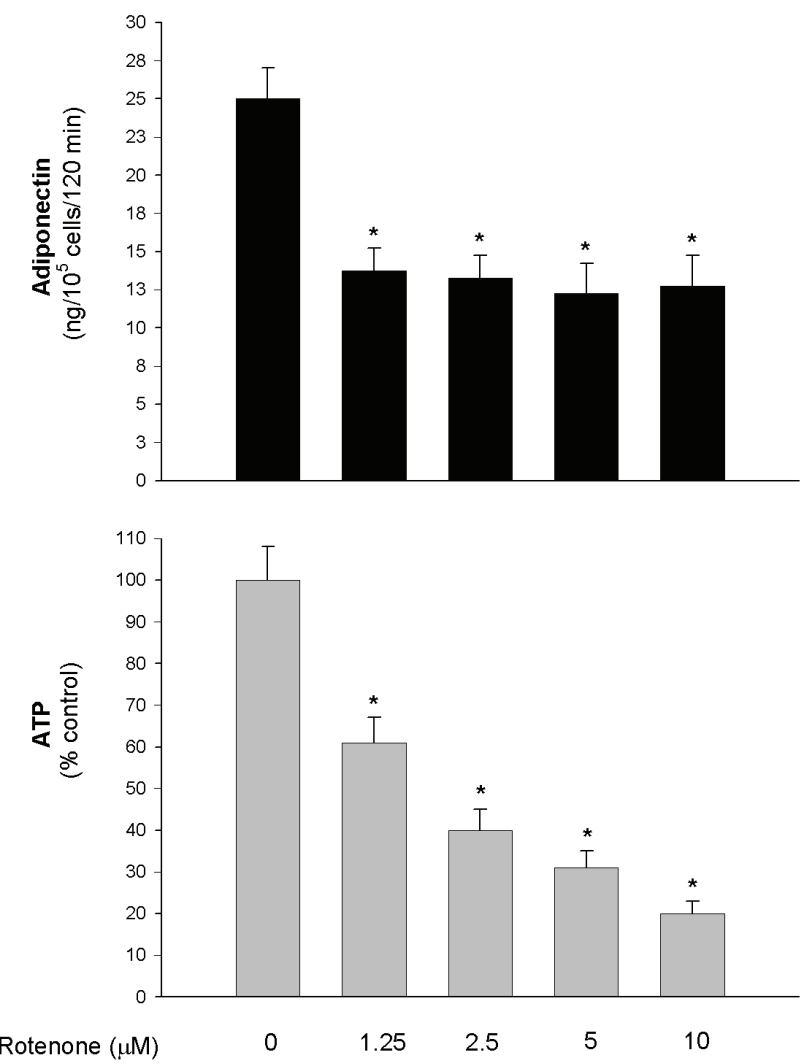

Fig. 6. The effect of rotenone on adiponectin secretion from isolated rat adipocytes (upper plot) or ATP concentrations in adipocytes (lower plot). Adipocytes were exposed to $5 \mathrm{mM}$ glucose and $10 \mathrm{nM}$ insulin without rotenone or in the presence of different concentrations of this compound. Bars represent mean \pm SEM of 12 determinations from 3 separate experiments. * Differences statistically significant vs. incubations without rotenone, $\mathrm{P}<0.05$.

2002, Szkudelski et al. 2005). Long-term exposure of adipocytes to different $\beta$-adrenergic agonists and cAMP analogues has been previously reported to down-regulate adiponectin mRNA (Cong et al. 2007). In the present study, secretion of adiponectin from fat cells incubated with glucose and insulin appeared to be reduced upon exposure for $2 \mathrm{~h}$ to 1 and $2 \mu \mathrm{M}$ epinephrine. However, under similar experimental conditions, 0.25 and $0.5 \mu \mathrm{M}$ epinephrine was ineffective. The lack of effects noticed at lowest concentrations of epinephrine may be explained by the presence of insulin in the incubation medium. Insulin activates cAMP phosphodiesterase 3B (PDE3B), diminishes cAMP in adipocytes and thereby attenuates effects of epinephrine (Smith et al. 1991, Eriksson et al. 1995).

This assumption is supported by results demonstrating that dibutyryl-cAMP, a cAMP analogue which is not decomposed by PDE3B, was more effective as an inhibitor of adiponectin secretion compared with 
epinephrine. Moreover, it was previously shown that in adipocytes exposed for $24 \mathrm{~h}$ to isoprenaline, the inhibitory effect of $\beta$-adrenergic agonist on adiponectin expression and secretion was suppressed by insulin (Cong et al. 2007).

Adipocyte-derived adenosine is another physiological candidate, acting via changes in cAMP in adipocytes, that could be implicated in the regulation of adiponectin secretion. Adenosine generated in adipocytes is known to regulate pivotal functions of these cells. The nucleoside is released from fat cells, binds to adenosine $A_{1}$ receptor, decreases cAMP content causing tonic inhibition of lipolysis and enhances the lipogenic and antilipolytic action of insulin (Londos et al. 1978, Liang et al. 2002, Szkudelski et al. 2009). It is well established that adenosine is one of the important factors regulating secretion of leptin (Rice et al. 2000, Cheng et al. 2000, Szkudelski 2007). Results of the present study revealed for the first time that adipocyte-derived adenosine is also involved in the short-term regulation of adiponectin secretion. This conclusion arises from the observation that adipocyte exposure to DPCPX, an antagonist of adenosine $\mathrm{A}_{1}$ receptor, resulted in a substantial inhibition of adiponectin secretion. This effect was accompanied by increased lipolysis indicating that the inhibitory effect of DPCPX on adiponectin secretion results from increased cAMP in adipocytes. Our results point that signaling via adenosine pathway in adipocytes is necessary for the proper secretion of adiponectin, whereas reduced action of adenosine decreases secretion of this adipokine. This may have pathophysiological relevance since the proper action of adenosine is known to be important in preventing obesity and insulin resistance (LaNoue and Martin 1994, Dong et al. 2001, Dhalla et al. 2007).

Data from the literature and results obtained in this study imply that the increase in cAMP plays an inhibitory role in both short- and long-term regulation of adiponectin secretion. The rise in cAMP concentration in adipocytes results, among others, in increased triglyceride breakdown and increased release of glycerol and fatty acids. It is possible that free fatty acids generated during lipolysis may be involved in the inhibitory effect of epinephrine and other lipolytic agents on adiponectin secretion. This effect was previously found in the case of leptin (Cammisotto et al. 2003). However, results of the present study demonstrated that palmitate failed to affect secretion of adiponectin. Similar lack of effects was demonstrated for 2-bromopalmitate, a nonmetabolisable palmitate analogue which is the inhibitor of mitochondrial palmitate carnitine transferase. These results indicate that the increase in concentration of fatty acids (at least to 0.5 $\mathrm{mM}$ ) or inhibition of their mitochondrial oxidation do not affect secretion of adiponectin from isolated rat adipocytes.

Previous studies demonstrated an important role of energy for the proper secretion of leptin from rat adipocytes (Levy et al. 2000). In the experiments studying the secretion of adiponectin from isolated adipocytes, a strong inverse relationship between the increase in anaerobic utilization of glucose and the decrease in adiponectin secretion after $96 \mathrm{~h}$ of incubation was shown (Pérez-Matute et al. 2007). In our present study, inhibition of ATP formation by rotenone, a potent and specific inhibitor of mitochondrial electron transport, resulted in a substantial deterioration of adiponectin secretion from fat cells incubated in the presence of glucose and insulin already after $2 \mathrm{~h}$ of incubation. Interestingly, the inhibitory effect resulting from ATP depletion was greater than the effect induced by epinephrine, dibutyryl-cAMP or DPCPX. These results indicate that different factors reducing ATP content in adipocytes may also decrease secretion of adiponectin. However, in our short-term studies, the inhibitory effect of rotenone on adiponectin secretion appeared not to be proportional to the depletion of ATP. This observation is in accord with our previous experiments in which secretion of leptin was investigated. In these studies, a dramatic reduction of ATP content in isolated adipocytes only slightly decreased secretion of leptin after $2 \mathrm{~h}$ of incubation. However, after $6 \mathrm{~h}$, the effect of ATP depletion on leptin secretion was significantly greater (Szkudelska et al. 2009). These results allow to conclude that in short-term regulation of adiponectin and leptin secretion, even a profound depletion of ATP in rat adipocytes causes significant, but not proportional to the decrease in intracellular energy, diminution in secretion of these adipokines.

In conclusion, our results demonstrated that secretion of adiponectin from epididymal rat adipocytes is susceptible to the short-term regulation by insulin, epinephrine, adenosine and energy deprivation. It was found that insulin potentiated adiponectin secretion after $2 \mathrm{~h}$ of incubation, whereas epinephrine exerted the opposite effect. Moreover, blockade of adenosine action or deprivation of energy caused a clear-cut inhibition of adiponectin secretion from isolated rat adipocytes. These findings provide new information on the short-term regulation of secretion of this adipokine in rat adipocytes. 


\section{Conflict of Interest}

There is no conflict of interest.

\section{Abbreviations}

DB-cAMP, dibutyryl-cAMP
$\left(\mathrm{N}^{6}, \quad\right.$ 2'-O-dibutyryl- adenosine 3', 5'-cyclic monophosphate sodium salt); DPCPX, 8-cyclopentyl-1,3-dipropylxanthine; DMSO, dimethyl sulfoxide; mTOR, mammalian target of rapamycin; HEPES, (N-[2-hydroxylethyl]piperazine-N'[2-ethanesulfonic acid])

\section{References}

ARITA Y, KIHARA S, OUCHI N, TAKAHASHI M, MAEDA K, MIYAGAWA J, HOTTA K, SHIMOMURA I, NAKAMURA T, MIYAOKA K, KURIYAMA H, NISHIDA M, YAMASHITA S, OKUBO K, MATSUBARA K, MURAGUCHI M, OHMOTO Y, FUNAHASHI T, MATSUZAWA Y: Paradoxical decrease of an adipose-specific protein, adiponectin, in obesity. Biochem Biophys Res Commun 257: 79-83, 1999.

BERG AH, COMBS TP, DU X, BROWNLEE M, SCHERER PE: The adipocyte-secreted protein Acrp30 enhances hepatic insulin action. Nature Med 7: 947-953, 2001.

CAMMISOTTO PG, BUKOWIECKI LJ: Mechanisms of leptin secretion from white adipocytes. Am J Physiol Cell Physiol 283: C244-C250, 2002.

CAMMISOTTO PG, GÉLINAS Y, DESHAIES Y, BUKOWIECKI LJ: Regulation of leptin secretion from white adipocytes by free fatty acids. Am J Physiol Endocrinol Metab 285: E521-E526, 2003.

CHENG JT, LIU IM, CHI TC, SHINOZUKA K, LU FH, WU TJ, CHANG CJ: Role of adenosine in insulin-stimulated release of leptin from isolated white adipocytes of Wistar rats. Diabetes 49: 20-24, 2000.

CONG L, CHEN K, LI J, GAO P, LI Q, L, MI S, WU X, ZHAO AZ: Regulation of adiponectin and leptin secretion by insulin through PI3K-PDE3B dependent mechanism in rat primary adipocytes. Biochem J 403: 519-525, 2007.

DHALLA AK, WONG MY, VOSHOL PJ, BELARDINELLI L, REAVEN GM: $\mathrm{A}_{1}$ adenosine receptor partial agonist lowers plasma FFA and improves insulin resistance induced by high-fat diet in rodents. Am J Physiol Endocrinol Metab 292: E1358-E1363, 2007.

DONG Q, GINSBERG HN, ERLANGER BF: Overexpression of the $\mathrm{A}_{1}$ adenosine receptor in adipose tissue protects mice from obesity-related insulin resistance. Diabetes Obes Metab 3: 360-366, 2001.

ERIKSSON H, RIDDERSTRÅLE M, DEGERMAN E, EKHOLM D, SMITH CJ, MANGANIELLO VC, BELFRAGE P, TORNQVIST H: Evidence for the key role of the adipocyte cGMP-inhibited cAMP phosphodiesterase in the antilipolytic action of insulin. Biochim Biophys Acta 1266: 101-107, 1995.

FOSTER LB, DUNN RT: Stable reagents for determination of serum triglycerides by a colorimetric Hantzsch condensation. Clin Chem 19: 338-340, 1973.

GAVRILA A, CHAN JL, YIANNAKOURIS N, KONTOGIANNI M, MILLER LC, ORLOVA C, MANTZOROS CS: Serum adiponectin levels are inversely associated with overall and central fat distribution but are not directly regulated by acute fasting or leptin administration in humans: cross-sectional and interventional studies. $J$ Clin Endocrinol Metab 88: 4823-4831, 2003.

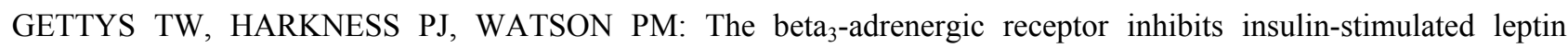
secretion from isolated rat adipocytes. Endocrinology 137: 4054-4057, 1996.

HALUZÍK M, PARÍZKOVÁ J, HALUZÍK MM: Adiponectin and its role in the obesity-induced insulin resistance and related complications. Physiol Res 53: 123-129, 2004.

HOTTA K, FUNAHASHI T, ARITA Y, TAKAHASHI M, MATSUDA M, OKAMOTO Y, IWAHASHI H, KURIYAMA H, OUCHI N, MAEDA K, NISHIDA M, KIHARA S, SAKAI N, NAKAJIMA T, HASEGAWA K, MURAGUCHI M, OHMOTO Y, NAKAMURA T, YAMASHITA S, HANAFUSA T, MATSUZAWA Y: Plasma concentrations of a novel, adipose-specific protein, adiponectin, in type 2 diabetic patients. Arterioscler Thromb Vasc Biol 20: 1595-1599, 2000.

HUYPENS P, MOENS K, HEIMBERG H, LING Z, PIPELEERS D, VAN DE CASTEELE M: Adiponectin-mediated stimulation of AMP-activated protein kinase (AMPK) in pancreatic beta cells. Life Sci 77: 1273-1282, 2005.

LANOUE KF, MARTIN LF: Abnormal A $\mathrm{A}_{1}$ adenosine receptor function in genetic obesity. FASEB $J$ 8: 72-80, 1994. 
LEAHY JL: Pathogenesis of type 2 diabetes mellitus. Arch Med Res 36: 197-209, 2005.

LEVY JR, GYARMATI J, LESKO JM, ADLER RA, STEVENS W: Dual regulation of leptin secretion: intracellular energy and calcium dependence of regulated pathway. Am J Physiol Endocrinol Metab 278: E892-E901, 2000.

LIANG HX, BELARDINELLI L, OZECK MJ, SHRYOCK JC: Tonic activity of the rat adipocyte $\mathrm{A}_{1}$-adenosine receptor. Br J Pharmacol 135: 1457-1466, 2002.

LINDSTRÖM T, FRYSTYK J, HEDMAN CA, FLYVBJERG A, ARNQVIST HJ: Elevated circulating adiponectin in type 1 diabetes is associated with long diabetes duration. Clin Endocrinol (Oxf) 65: 776-782, 2006.

LONDOS C, COOPER DM, SCHLEGEL W, RODBELL M: Adenosine analogs inhibit adipocyte adenylate cyclase by a GTP-dependent process: basis for actions of adenosine and methylxanthines on cyclic AMP production and lipolysis. Proc Natl Acad Sci USA 75: 5362-5366, 1978.

MATSUBARA M, MARUOKA S, KATAYOSE S: Inverse relationship between plasma adiponectin and leptin concentrations in normal-weight and obese women. Eur J Endocrinol 147: 173-180, 2002.

MOTOSHIMA H, WU X, SINHA MK, HARDY VE, ROSATO EL, BARBOT DJ, ROSATO FE, GOLDSTEIN BJ: Differential regulation of adiponectin secretion from cultured human omental and subcutaneous adipocytes: effects of insulin and rosiglitazone. J Clin Endocrinol Metab 87: 5662-5667, 2002.

MULLEN KL, PRITCHARD J, RITCHIE I, SNOOK LA, CHABOWSKI A, BONEN A, WRIGHT D, DYCK DJ: Adiponectin resistance precedes the accumulation of skeletal muscle lipids and insulin resistance in high-fatfed rats. Am J Physiol Regul Integr Comp Physiol 296: R243-R251, 2009.

NEDVÍDKOVÁ J, SMITKA K, KOPSKÝ V, HAINER V: Adiponectin, an adipocyte-derived protein. Physiol Res 54: 133-140, 2005.

PECZYŃSKA J, URBAN M, GLOWIŃSKA B, FLORYS B: Evaluation of adiponectin level in children and adolescents with diabetes type 1. Pediatr Endocrinol Diabetes Metab 14: 77-81, 2008.

PÉREZ-MATUTE P, MARTI A, MARTÍNEZ JA, FERNÁNDEZ-OTERO MP, STANHOPE KL, HAVEL PJ, MORENO-ALIAGA MJ: Conjugated linoleic acid inhibits glucose metabolism, leptin and adiponectin secretion in primary cultured rat adipocytes. Mol Cell Endocrinol 268: 50-58, 2007.

RABE K, LEHRKE M, PARHOFER KG, BROEDL UC: Adipokines and insulin resistance. Mol Med 14: 741-751, 2008.

RICE AM, FAIN JN, RIVKEES SA: $\mathrm{A}_{1}$ adenosine receptor activation increases adipocyte leptin secretion. Endocrinology 141: 1442-1445, 2000.

RODBELL M: Metabolism of isolated fat cells. J Biol Chem 239: 375-380, 1964.

SMITH CJ, VASTA V, DEGERMAN E, BELFRAGE P, MANGANIELLO VC: Hormone-sensitive cyclic GMPinhibited cyclic AMP phosphodiesterase in rat adipocytes. Regulation of insulin- and cAMP-dependent activation by phosphorylation. J Biol Chem 266: 13385-13390, 1991.

SZKUDELSKA K, NOGOWSKI L, SZKUDELSKI T: Genistein affects lipogenesis and lipolysis in isolated rat adipocytes. J Steroid Biochem Mol Biol 75: 265-271, 2000.

SZKUDELSKA K, NOGOWSKI L, SZKUDELSKI T: The inhibitory effect of resveratrol on leptin secretion from rat adipocytes. Eur J Clin Invest 39: 899-905, 2009.

SZKUDELSKI T, NOWICKA E, SZKUDELSKA K: Leptin secretion and protein kinase A activity. Physiol Res 54: 79-85, 2005.

SZKUDELSKI T, SZKUDELSKA K, NOGOWSKI L: Effects of adenosine $\mathrm{A}_{1}$ receptor antagonism on lipogenesis and lipolysis in isolated rat adipocytes. Physiol Res 58: 863-871, 2009.

SZKUDELSKI T: Intracellular mediators in regulation of leptin secretion from adipocytes. Physiol Res 56: 503-512, 2007.

WANG C, MAO X, WANG L, LIU M, WETZEL MD, GUAN KL, DONG LQ, LIU F: Adiponectin sensitizes insulin signaling by reducing p70 S6 kinase-mediated serine phosphorylation of IRS-1. J Biol Chem 282: 7991-7996, 2007.

WEYER C, FUNAHASHI T, TANAKA S, HOTTA K, MATSUZAWA Y, PRATLEY RE, TATARANNI PA: Hypoadiponectinemia in obesity and type 2 diabetes: close association with insulin resistance and hyperinsulinemia. J Clin Endocrinol Metab 86: 1930-1935, 2001. 
YAMAMOTO Y, HIROSE H, SAITO I, TOMITA M, TANIYAMA M, MATSUBARA K, OKAZAKI Y, ISHII T, NISHIKAI K, SARUTA T: Correlation of the adipocyte-derived protein adiponectin with insulin resistance index and serum high-density lipoprotein-cholesterol, independent of body mass index, in the Japanese population. Clin Sci (Lond) 103: 137-142, 2002.

YAMAUCHI T, KAMON J, ITO Y, TSUCHIDA A, YOKOMIZO T, KITA S, SUGIYAMA, T, MIYAGISHI M, HARA K, TSUNODA M, MURAKAMI K, OHTEKI T, UCHIDA S, TAKEKAWA S, WAKI H, TSUNO NH, SHIBATA Y, TERAUCHI Y, FROGUEL P, TOBE K, KOYASU S, TAIRA K, KITAMURA T, SHIMIZU T, NAGAI R, KADOWAKI T: Cloning of adiponectin receptors that mediate antidiabetic metabolic effects. Nature 423: 762-769, 2003.

YAMAUCHI T, KAMON J, MINOKOSHI Y, ITO Y, WAKI H, UCHIDA S, YAMASHITA S, NODA M, KITA S, UEKI K, ETO K, AKANUMA Y, FROGUEL P, FOUFELLE F, FERRE P, CARLING D, KIMURA S, NAGAI R, KAHN BB, KADOWAKI T: Adiponectin stimulates glucose utilization and fatty-acid oxidation by activating AMP-activated protein kinase. Nature Med 8: 1288-1295, 2002.

YAMAUCHI T, KAMON J, WAKI H, TERAUCHI Y, KUBOTA N, HARA K, MORI Y, IDE T, MURAKAMI K, TSUBOYAMA-KASAOKA N, EZAKI O, AKANUMA Y, GAVRILOVA O, VINSON C, REITMAN ML, KAGECHIKA H, SHUDO K, YODA M, NAKANO Y, TOBE K, NAGAI R, KIMURA S, TOMITA M, FROGUEL P, KADOWAKI T: The fat-derived hormone adiponectin reverses insulin resistance associated with both lipoatrophy and obesity. Nature Med 7: 941-946, 2001.

ZHANG Y, MATHENY M, ZOLOTUKHIN S, TUMER N, SCARPACE PJ: Regulation of adiponectin and leptin gene expression in white and brown adipose tissues: influence of beta3-adrenergic agonists, retinoic acid, leptin and fasting. Biochim Biophys Acta 1584: 115-122, 2002.

ZIEMKE F, MANTZOROS CS: Adiponectin in insulin resistance: lessons from translational research. Am J Clin Nutr 91: 258-261, 2010. 